\title{
Improving Waste Added Value in Rabbit Farmers Group in Pancasari Village, Buleleng
}

\author{
Anak Agung Ngurah Mayun Wirajaya ${ }^{1}$, Made Sri Yuliartini ${ }^{2}$, I Gusti Bagus Udayana ${ }^{3}$ \\ \{mawir61@yahoo.com\} \\ Lecturer in Agrotechnology Study Program, Faculty of Agriculture, Warmadewa University
}

\begin{abstract}
This study aims to improve the waste added value in rabbit farmers group at the Wana Sari Merta Livestock Farmer Group in Pancasari Village, Sukasada Sub-district, Buleleng Regency, Bali Province. Pancasari Village is a horticultural area that uses organic fertilizer derived from chicken manure for its agricultural purposes, therefore the use of rabbit farming community as an opportunity to supply organic fertilizer from solid has not been initially conducted. Before now, the problems faced by partners are 1) solid and liquid waste are not optimally processed, with the intensive production of organic fertilizer , 2) they do not have a building that holds and processes solid and liquid waste for fermentation and product storage activities, 3) the product has not been properly packaged, 4). the disease which attacks rabbits is still high and leads to death, and 5). lack of food during dry season. The solutions used in overcoming the problems are counseling and technical guidance for 1). making solid and liquid organic fertilizer, 2). constructing buildings to process solid and liquid waste, 3). packing of solid and liquid organic fertilizers, 4). prevention of diseases, and 5). finding alternative foods. The purpose of this PKM activity is to increase partners' knowledge and skills in rabbit cultivation and utilize its solid and liquid waste as organic fertilizer in substituting the use of the inorganic in the partner area. Furthermore, solid and liquid waste of the rabbits are used as organic fertilizer for cultivated plants in addition to the current use of organic fertilizers from chicken manure. The involvement of technology in processing rabbit waste provides high added value for partner livestock farmers. The result showed that the partner group is independently able to properly utilize solid and liquid rabbit waste into "Solid Organic Fertilizer" (POP) and "Liquid Organic Fertilizer" (POC) to increase partner group income.
\end{abstract}

Keywords: livestock farmer groups, rabbits, rabbit waste, solid organic fertilizer, liquid organic fertilizer.

\section{Pendahuluan}

\subsection{Analisis Situasi}

Desa Pancasari terletak di Kecamatan Sukasada yang berada di bagian paling selatan Kabupaten Buleleng merupakan salah satu dari desa dengan luas wilayah $12,80 \mathrm{~km}^{2}$ dan 
merupakan daerah perbukitan dengan ketinggian $1.250 \mathrm{~m}$ dari permukaan laut. Jarak dari ibukota Provinsi Bali Denpasar 59,0 km. Adapun batas-batas wilayahnya adalah :

Sebelah Utara : Desa Wanagiri-Kecamatan Sukasada

Sebelah Timur : Hutan Negara

Sebelah Selatan :Desa Candikuning-Kecamatan Baturiti

Sebelah Barat : Hutan Negara

Secara administrasi Desa Pancasari terdiri dari 5 (lima) banjar dinas yaitu : 1). Banjar Dinas Buyan, 2). Banjar Dinas Peken ,3). Banjar Dinas Dasong ,4). Banjar Dinas Karma , 5). Banjar Dinas Lalang Linggah (Profil Desa Pancasari, 2017).

Desa Pancasari yang terletak di dekat dua danau yaitu danau Buyan dan danau Tamblingan, sebagian besar masyarakatnya menggantungkan hidupnya pada sektor pertanian, peternakan, perkebunan. Di sektor pertanian, komoditas yang dikembangkan oleh petani sebagian besar berupa tanaman hortikultura yang tumbuh dan berkembang dengan baik sangat didukung oleh iklim disekitarnya. Dalam Profil Desa Pancasari (2017) disebutkan sebagian besar petani menanam tanaman hortikultura berupa cabai, tomat, sawi, kentang, brokoli, selada, wortel, stroberi dan lainnya. Sebagian besar produk hasil pertanian petani dijual untuk kepentingan pemenuhan kebutuhan pariwisata selain dijual kepasar-pasar tradisional yang ada diseluruh Bali.

Produk pertanian yang dihasilkan oleh petani agar dapat mempunyai kualitas dan kuantitas yang sesuai dengan kebutuhan pasar dan agar kesuburan tanah tetap memberi dukungan pada produk yang dihasilkan dibutuhkan pupuk. Petani dalam pemupukan masih mempergunakan pupuk organik dan an organik dalam budidaya tanaman hortikulturanya. Sampai saat ini petani masih dominan menggunakan pupuk organik berupa pupuk kandang ayam dalam pemenuhan luasan penanaman yang cukup luas yang sebagian besar dibeli dari luar daerah Pancasari. Memperhatikan masih banyaknya potensi limbah dari hewan yang dapat dipakai sebagai pupuk organik dan cukup besarnya kebutuhan akan pupuk organik, maka kelinci yang cukup banyak dipelihara oleh petani ternak kelinci di Pancasari menjadi salah satu alternatif pemenuhan kebutuhan pupuk organik dari limbah kelinci sangat terbuka lebar. Dalam Profil Desa Pancasari (2017) tercatat peternak kelinci sebanyak 112 orang dengan jumlah kelinci 1.500 ekor. Walaupun keberadaan kelinci dan limbahnya cukup tersedia, namun masih kurang mendapat perhatian dari petani untuk memanfaatkannya sebagai sumber pupuk organik. Setiawan (2007) menyatakan bahwa dalam mengatasi permasalahan bagaimana mengurangi risiko pencemaran yang ditimbulkan oleh kotoran ternak, dapat dilakukan dengan 3 (tiga) pilihan yaitu : 1).untuk pupuk ,2).penghasil biogas, dan 3).bahan pembuat bioarang.

Kandungan unsur hara dari limbah kotoran kelinci lebih baik dari beberapa pupuk organik/pupuk kandang lainnya sebenarnya memberi harapan bagi petani untuk mengelola kelinci dengan baik dan memanfaatkan kotorannya semaksimal mungkin guna meningkatkan produksi tanaman. Balittanah (2006 dalam Sembiring dkk., 2017) menyebutkan pupuk organik cair yang berasal dari urin kelinci mempunyai kandungan unsur hara yang cukup tinggi yaitu $\mathrm{N}$ $4 \%, \mathrm{P}_{2} \mathrm{O}_{5} 2,8 \%$, dan $\mathrm{K}_{2} \mathrm{O} 1,2 \%$ relatif lebih tinggi daripada kandungan unsur hara pada sapi ( $\mathrm{N}$ $1,21 \%, \mathrm{P}_{2} \mathrm{O}_{5} 0,65 \%$, dan $\left.\mathrm{K}_{2} \mathrm{O} 1,6 \%\right)$ dan kambing $\left(\mathrm{N} \mathrm{1,47 \% ,} \mathrm{P}_{2} \mathrm{O}_{5}\right.$ 0,05\%, dan $\left.\mathrm{K}_{2} \mathrm{O} 1,96 \%\right)$. Kandungan feses kelinci dimana satu ekor kelinci yang berusia dua bulan lebih, atau yang beratnya sudah mencapai $1 \mathrm{~kg}$ akan menghasilkan 28,0 g kotoran lunak per hari dan mengandung 3 g protein serta 0,35 g nitrogen dari bakteri atau setara 1,3 g protein. (Spreaadburi dan Yono C. Rahardjo: 1978 dalam Erika Dewi dan Paiman, 2011). Zulkarnain (2009) menyatakan bahwa pemakaian pupuk organik perlu ditingkatkan dan mendapat prioritas tidak hanya untuk meningkatkan kesuburan tanah, tetapi juga untuk membantu menciptakan agroekosistem yang berkesinambungan dan aman bagi kesehatan manusia. 
Guna terlaksananya pemanfaatan limbah padat dan cair kelinci dapat dilakukan dengan pemberdayaan anggota kelompok lebih baik. Wrihatnolo dan Riant Nugroho (2007) menyatakan bahwa pemberdayaan pada dasarnya menempatkan masyarakat sebagai pusat perhatian dan sekaligus pelaku utama pembangunan (people-centre development).

Pelaksanaan Program Kemitraan Masyarakat (PKM) akan bermitra dengan 1 (satu) kelompok tani ternak yang memiliki kemauan kuat untuk maju dan mengelola usahanya dengan baik yaitu kelompok "WANA SARI MERTA" yang terdiri dari 5 orang anggota dan diketuai oleh Kadek Sutama, jumlah kelinci dipelihara sebanyak 60 ekor dengan kandang yang sederhana. Program ini akan diarahkan pada usaha pemeliharaan dan pemanfaatan limbah kelinci dengan baik, bangunan penampung limbah serta sebagai tempat fermentasi, pengemasan dan labeling produk, serta usaha/bisnis limbah kelinci dalam bentuk "Pupuk Organik Padat" dan "Pupuk Organik Cair".

Berdasarkan hasil observasi dilapang dapat diperoleh informasi permasalahan yang dihadapi mitra yaitu : 1). Limbah padat dan cair belum diolah secara optimal dan memproses /memproduksi pupuk organik dari limbah tersebut belum secara intensif/hanya sewaktu-waktu ,2).Belum memiliki bangunan tempat penampung dan pengolahan limbah padat dan cair untuk kegiatan fermentasi dan penyimpanan produk, 3). Produk belum dikemas dengan baik, 4). Penyakit yang masih tinggi menyerang dan dapat menyebabkan kematian kelinci, 5). Kekurangan makanan saat musim kemarau.

Anggota kelompok tani ternak mitra, sebagian besar menjalankan usaha dengan beternak dan bertani tanaman hortikultura. Dari usaha yang dijalankan diberbagai bidang diharapkan dapat membantu keluarga dalam peningkatan pendapatannya. Memanfaatkan kotoran kelinci yang sebelumnya tidak dipandang merupakan pekerjaan mengisi waktu yang menguntungkan. Diharapkan dengan adanya pengabdian kepada masyarakat yang didanai oleh Lembaga Pengabdian Masyarakat Universitas Warmadewa, masyarakat Desa Pancasari di kelompok tani ternak "Wana Sari Merta" akan mengalami peningkatan kemampuan kelompok pada sumberdaya manusianya, pendapatan dari besarnya manfaat yang didapat dari limbah kelinci utamanya untuk budidaya tanaman. 


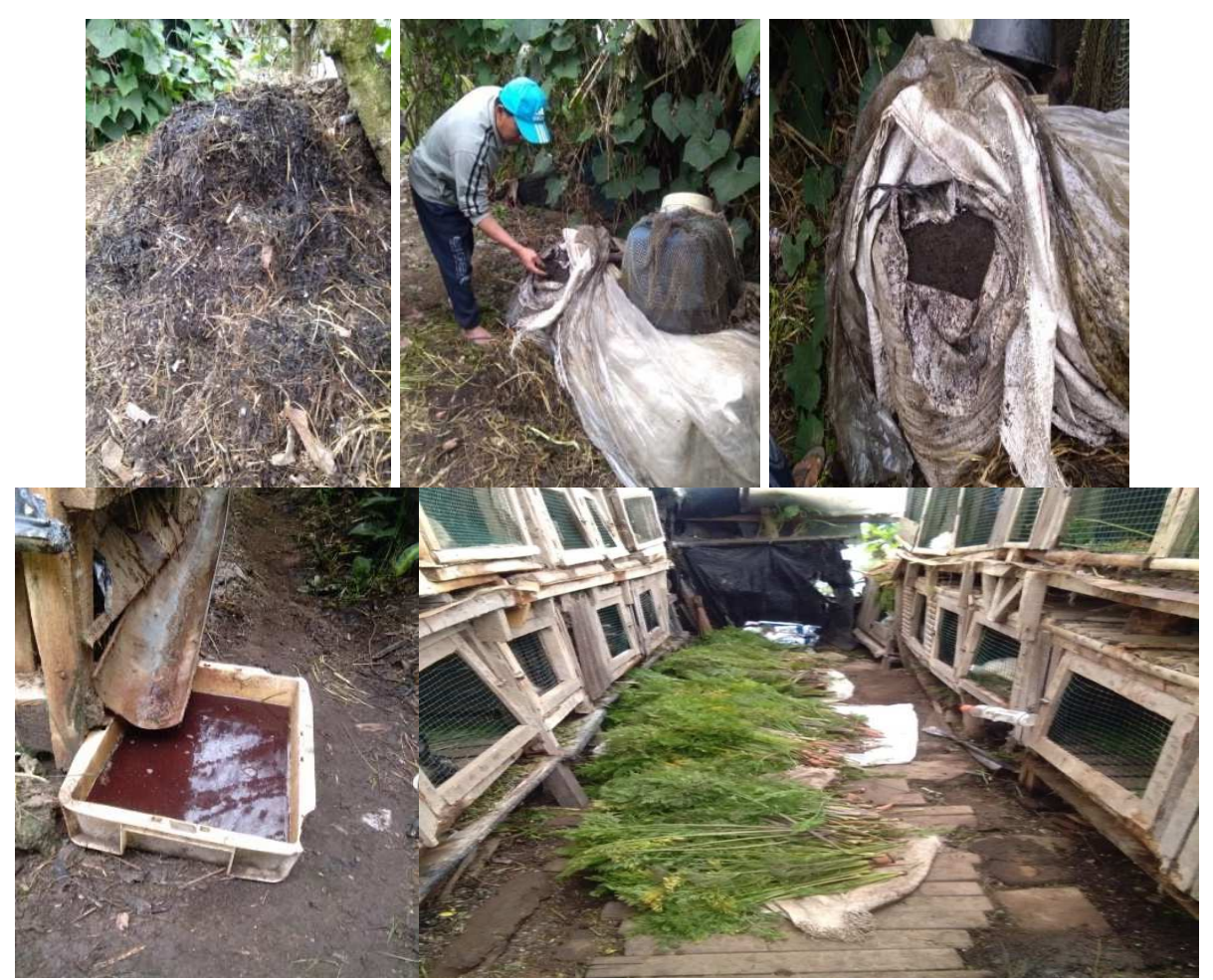

Gambar 1 Umum Kondisi Mitra

\subsection{Tujuan Kegiatan}

Tujuan kegiatan yang ingin dicapai pada kegiatan ini adalah :

1. Pemahaman teknologi pengolahan limbah ternak kelinci menjadi pupuk dan mampu membuat/memproduksi pupuk organik padat dan cair yang berkualitas dan bernilai ekonomi tinggi bagi kelompok mitra semakin meningkat.

2. Kelompok mitra memiliki kemampuan manajemen usaha yang lebih baik.

3. Membantu menciptakan ketentraman dan kenyamanan dalam kehidupan bermasyarakat.

\subsection{Manfaat Kegiatan}

1. Bagi kelompok mitra akan meningkatkan pendapatan dan kesejahteraan anggotanya melalui usaha pengembangan pupuk organik kelinci dan kemandirian mitra.

2. Bagi Lembaga diharapkan kegiatan ini dipakai sebagai model pemberdayaan masyarakat dan dapat dipakai sebagai tempat pengembangan penelitian-penelitian

3. Bagi Pemerintah diharapkan kegiatan ini dapat dipakai sebagai upaya pemberdayaan masyarakat dan menjadi model pengembangan dalam peningkatan kesejahteraan masyarakat.

\subsection{Tempat dan Waktu Pelaksanaan}

Pelaksanaan pengabdian masyarakat diselenggarakan di Kelompok Tani Ternak "Wana Sari Merta" di Desa Pancasari Kecamatan Sukasada, Kabupaten Buleleng-Provinsi Bali. Waktu pelaksanaan dimulai saat proposal PKM ini disetujui oleh Lembaga Pengabdian Kepada 
Masyarakat Universitas Warmadewa pada awal tahun 2019 dan berlangsung sampai akhir tahun 2019.

\subsection{Metode Pendekatan}

Dalam perencanaan pengabdian masyarakat ini metode yang akan digunakan untuk memudahkan serta melancarkan dalam penyerapan materi maka dilakukan :

1. Metode wawancara dan diskusi untuk mengetahui masalah yang dihadapi oleh mitra kerja

2. Motode penyuluhan melalui tatap muka secara langsung, agar peserta didik mendapatkan ilmu pengetahuan mengenai penerapan teknologi pemanfaatan kotoran kelinci untuk pupuk dan tersedia secara kontinu dengan memperhatikan kualitas dan kuantitas produk serta membangkitkan jiwa kewirausahaan dan manajemen usaha.

3. Praktek langsung akan dipandu oleh instruktur yang berkompeten dibidangnya sehingga peserta didik dapat membuat langsung produk olahannya dan pendampingan.

\section{Hasil Dan Pembahasan}

Universitas Warmadewa dalam menjalankan pengabdian kepada masyarakat merupakan salah satu kegiatan Tridharma diharapkan dapat membantu masyarakat khususnya pada kelompok tani ternak di Desa Pancasari memanfaatkan limbah kelinci agar memberi nilai tambah dari hasil olahannya.. Dari permasalahan yang dihadapi oleh kelompok tani ternak "Wana Sari Merta" maka melalui proses diskusi, penyuluhan, praktek langsung, pendampingan beberapa solusi yang telah dilaksanakan dan berhasil adalah:

\subsection{Teknologi Proses Pengolahan Kotoran Kelinci dan SDM}

Pupuk organik padat dan pupuk organik cair yang dihasilkan oleh mitra kualitas produknya masih rendah. Dalam menjalankan kegiatan budidaya kelinci sumber daya manusia memegang peranan yang sangat penting. Kotoran kelinci yang menjadi bagian dari budidaya kelinci dapat memberi manfaat bila dikelola dengan baik sebagai pupuk dan itu terwujud bila kemampuan sumberdaya manusia yang melakukan kegiatannya memadai untuk mengolahnya dengan benar. Kotoran kelinci yang telah ada di kelompok ini cukup banyak namun perlu ditingkatkan kualitasnya dengan memberi penyuluhan, pelatihan dan pendampingan sehingga dapat menjadi hasil tambahan selain kelinci yang dijual sebagai sumber penghasilan yang utama. Ini telah dilakukan melalui pemberian materi penyuluhan, pelatihan dan pendampingan di lapang. Telah didapat bahwa petani paham dan mau untuk memanfaatkan kotoran kelinci untuk ditingkatkan mutunya dengan pemberian bahan-bahan tambahan untuk fermentasi yang dapat menguntungkan dan dikemas secara sederhana untuk dapat dipasarkan lebih luas. Sentuhan teknologi melalui pelatihan dan bimbingan teknis proses fermentasi dan pemberian EM 4, molase/gula merah, dan tambahan lainnya akan menjadikan produk limbah padat dan cair kelinci akan lebih bermutu. 


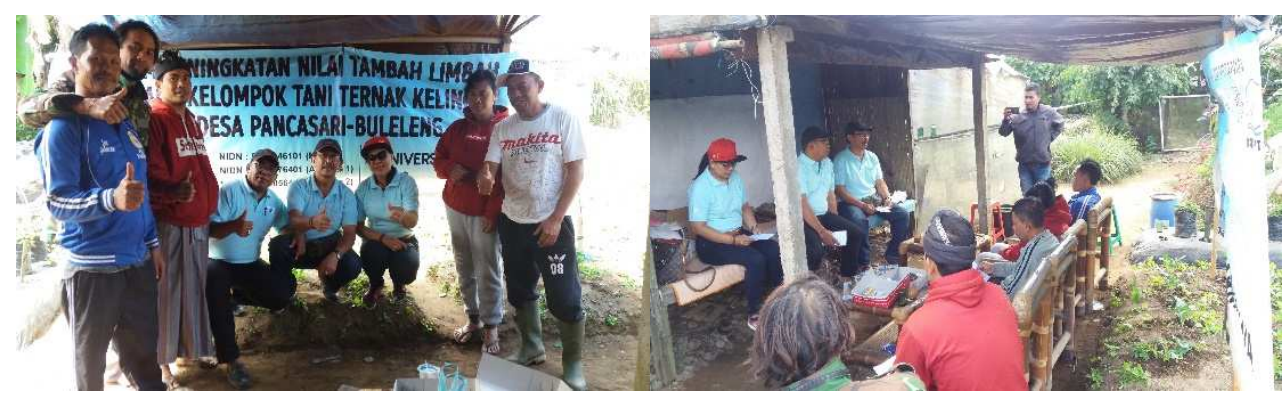

Gambar 2. Kelompok "Wana Sari Merta" saat penyuluhan

\subsection{Bangunan Penyimpanan dan Proses Fermentasi}

Kotoran yang dihasilkan oleh budidaya kelinci pada kelompok Wana Sari Merta di Pancasari cukup banyak. Saat ini kotoran padat maupun cair kelinci yang dapat memberikan nilai tambah dari kualitas dan kuantitas belum ditampung dan diproses pada tempat maupun bangunan yang representatif. Telah dilakukan penyuluhan dan bimbingan teknis tentang pembuatan bangunan yang representatif untuk penampungan, proses fermentasi dan penyimpanan produk. Dengan bahan bangunan yang cukup baik beratap seng, dinding ditutupi dengan seng plastik guna menghindari hujan dan masuknya sinar matahari langsung serta alas proses fermentasi berupa terpal plastik menjadikan bangunan yang tersedia cukup bagus dan diharapkan selama proses pembuatan pupuk organic padat dan pupuk organic cair menghasilkan produk akhir yang bermutu.

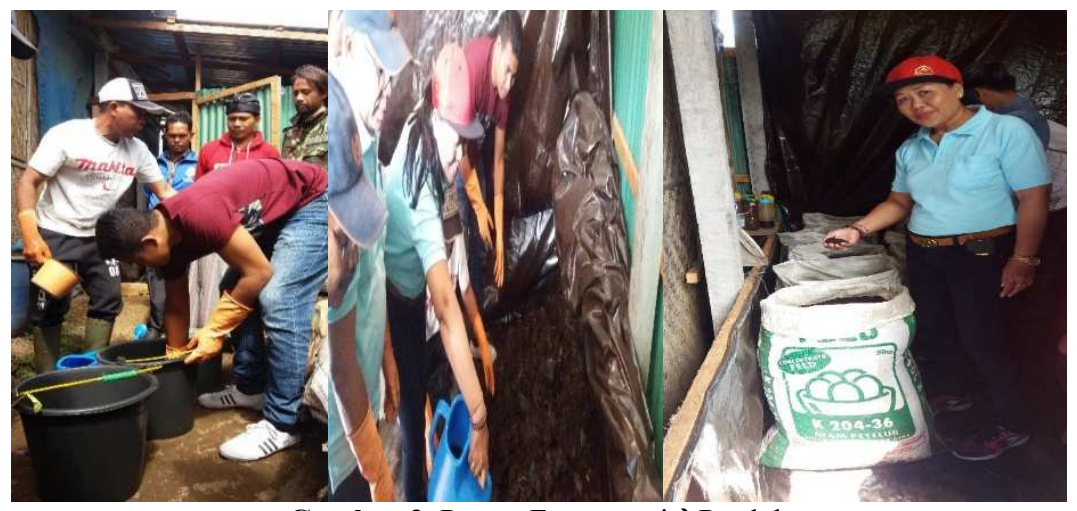

Gambar 3. Proses Fermentasi $\rightarrow$ Produk

\subsection{Pengemasan Produk}

Pupuk organik padat (POP) dan pupuk organik cair (POC) kelinci dari kelompok mitra dijual dipasaran hanya dengan pengemasan yang sederhana di lokasi sekitar lokasi kelompok mitra. Penyuluhan, pelatihan dan bimbingan teknis pengemasan akan dilakukan agar produk yang dihasilkan secara komersial dapat bersaing lebih luas dipasar dan dapat dikemas dengan baik, menarik serta mempunyai merek dagang agar mudah diingat serta mudah dicari oleh konsumen. Telah dilakukan pelatihan pengemasan dengan menggunakan bahan pengemas plastik dan alat pengemas yang sangat sederhana untuk dapat dijual lebih luas untuk hasil fermentasi olahan kotoran padat walaupun belum dibarengi merk dagang dan kandungan yang dimiliki oleh kotoran kelinci padat yang ditampilkan pada kemasan tersebut. Untuk pupuk organik cair lebih banyak dijual dalam bentuk literan tanpa pengemasan namun bila ada 
pemesanan secara khusus maka dibuatkan dengan proses fermentasi dengan menambah EM4 dan molase, dimana produk tersebut dikemas dengan menggunakan penampung sederhana dari botol plastik bekas tanpa labeling. Untuk mendapatkan tempat dipasar dan bersaing dengan produk pupuk organik padat dan cair lainnya, pengemasan perlu dilakukan dengan baik mengingat kotoran kelinci mempunyai kelebihan nilai kandungan unsur hara bila dibandingkan dengan pupuk organik dari kotoran ternak lainnya.
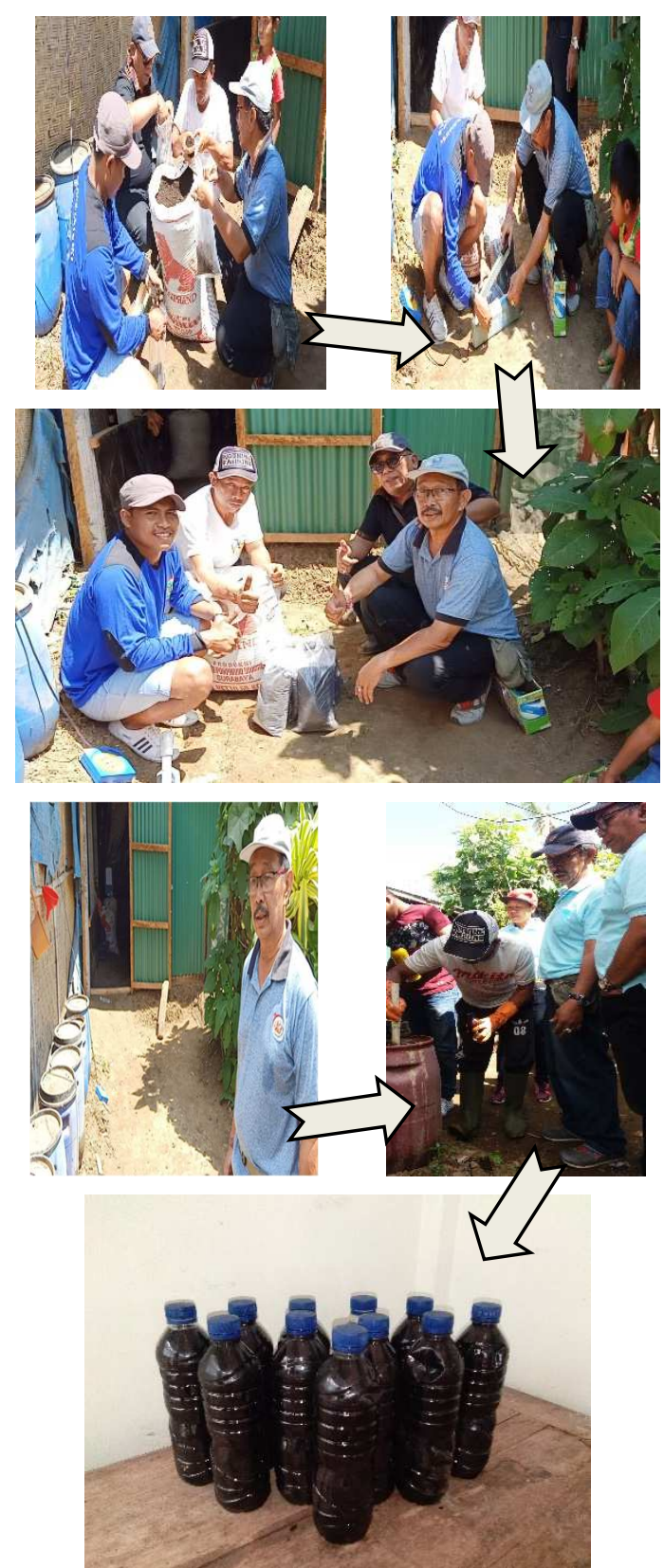

Gambar 4. Pupuk Organik Padat dan Pupuk Organik Cair dengan pengemasan yang sangat sederhana 


\section{4 Pencegahan Penyakit}

Dari kondisi di lapang, pada budidaya kelinci dalam pertumbuhannya di kelompok tani ini terdapat serangan penyakit sampai menyebabkan kematian pada ternak kelinci yang dipelihara adalah mencret. Penyakit ini dapat disebabkan oleh banyak hal antara lain faktor makanan, perubahan iklim dan lainnya, maka dalam pengabdian ini diberikan solusinya dengan memperhatikan makanan yang diberikan, kandang yang bersih, serta diberikan obat-obatan. Dari hasil pengamatan dilapang selama kegiatan pengabdian kepada masyarakat telah dirasakan adanya penurunan secara signifikan pada kelinci terhadap kesehatannya dengan memperhatikan saran saat penyuluhan dan praktik di lapang. Mitra telah mampu dan mau mengikuti saran yang diberikan sehingga kondisi kelinci tetap sehat.

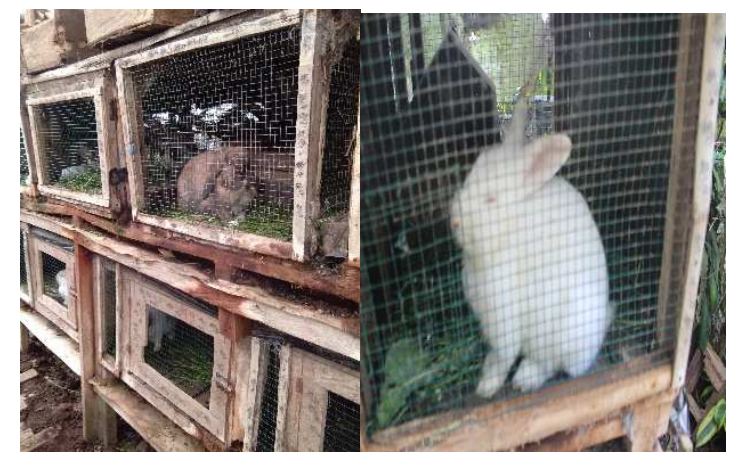

\subsection{Makanan Ternak}

Kualitas, kuantitas dan kontinuitas makan merupakan salah satu kunci keberhasilan dalam budidaya kelinci. Pada kelompok tani Wana Sari Merta pada musim kemarau ketersediaan makanan sering menjadi masalah. Telah dilakukan pemberian makanan yang bersumber dari tanaman jenis rumput yang tumbuh di sekitar tempat usaha. Saat musim kemarau sering dijumpai kondisi dimana rumput yang menjadi makanan andalan ketersediaannya sangat terbatas, namun untuk tetap memberikan pertumbuhan dan kesehatan kelinci terus dicarikan solusi dengan memanfaatkan makanan dari tanaman hortikultura yang merupakan sisa antara lain daun kol, wortel dan jenis lainnya yang selalu dicoba dan tetap melakukan inovasi untuk mendapatkan sumber makanan yang bermutu serta tetap tersedia agar kelinci dapat tumbuh dan berkembang dengan baik.

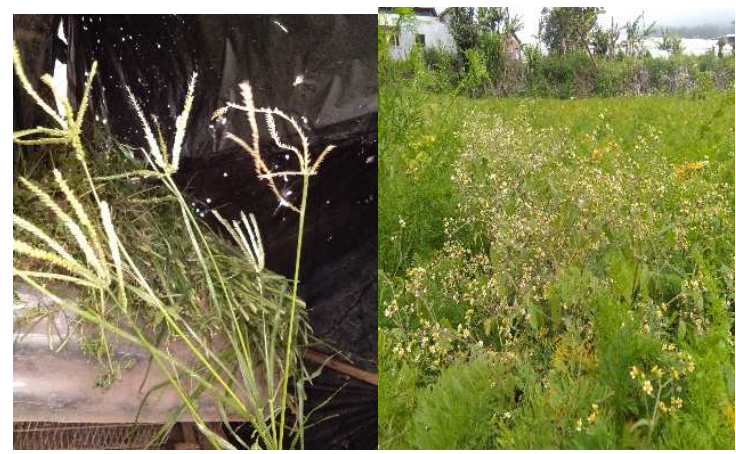

Gambar 5. Berbagai jenis makanan kelinci 
Kelompok Tani Ternak "Wana Sari Merta" dengan masing-masing anggotanya telah mengikuti penyuluhan, berinteraksi saat penyuluhan, praktek dilapang, pendampingan telah menunjukkan adanya kesungguhan dalam pemecahan masalah yang dihadapi.

\section{Kesimpulan}

Kelompok mitra tani ternak "Wana Sari Merta" di Desa Pancasari dalam pengabdian ini telah mampu mengadopsi segala materi yang diberikan. Terbukti dalam upaya meningkatkan kualitas, kuantitas dan kontinuitas dari produk kotoran kelinci kelompok mitra telah mau dan mampu mewujudkan bangunan agar dapat dipakai untuk proses pengolahan, fermentasi dan penyimpanan produk yang telah dihasilkan. Semakin baik tempat pengolahan produk kotoran kelinci diharapkan dapat menghasilkan produk olahan sesuai dengan rencana. Penerapan teknologi dalam proses fermentasi dapat dilakukan dengan baik. Produk dalam bentuk pupuk organik padat (POP) dan pupuk organik cair (POC) telah dilakukan pengemasan namun masih sangat sederhana dan diharapkan dapat bersaing dengan pupuk organik yang telah ada dipasaran serta lebih mudah untuk dipasarkan dan dapat dikenal lebih luas. Dengan pemanfaatan kotoran dan ditampung dengan baik dan bersih akan memberi kontribusi tingkat pertumbuhan dan perkembangan kelinci semakin baik sehingga kelinci sehat dan tidak mudah terserang penyakit selain akibat makanan dan perubahan cuaca. Sumber makanan yang menjadi kendala saat musim kemarau telah dicarikan jenis makanan yang cocok disekitar lokasi dan melakukan inovasi campuran yang tepat. Pengabdian peningkatan kotoran kelinci ini dapat menjadi sumber tambahan pendapatan masyarakat petani ternak dan memiliki prospek yang baik sehingga perlu disosialisasikan pada kelompok tani yang lain.

\section{References}

[1] Erika Dewi Nugraheni dan Paiman , 2011. Budidaya Tanaman Cabai Merah. Surakarta , Universitas Sebelas Maret.

[2] Profil Desa Pancasari, 2017. Profil Desa dan Kelurahan, Desa Pancasari, Kecamatan Sukasada, Kabupaten Buleleng-Provinsi Bali.

[3] Sembiring, Melda Yuartaria ; Lilik Setyobudi ; Yogi Sugito, 2017. Pengaruh Dosis Pupuk Urin Kelinci Terhadap Pertumbuhan dan Hasil Beberapa Varietas Tomat. Jurnal Produksi Tanaman, Vol. 5 No.1, Januari 2017: 132-139, ISSN; 2527-8452. Universitas Brawijaya-Malang.

[4] Setiawan,Ade Irawan , 2007. Memanfaatkan Kotoran Ternak ; Solusi Masalah Lingkungan dan Pemanfaatan Energi Alternatif. Penerbit Penebar Swadaya-Jakarta.

[5] Wrihatnolo,Randy R dan Riant Nugroho Dwidjowijoto, 2007. Manajemen Pemberdayaan; Sebuah Pengantar dan Panduan Untuk Pemberdayaan Masyarakat. Penerbit Elex Media Komputindo, Kelompok Gramedia-Jakarta.

[6] Zulkarnain, H. , 2009. Dasar-dasar Hortikultura. Penerbit PT. Bumi Aksara-Jakarta 